\title{
The Need for a Modernized EU-Turkey Customs Union: The Problems and the Solution Suggestions
}

\author{
By Azime Aslı Bilgin*
}

The Customs Union (CU), entered into force in 1996, was formed between Turkey and the European Union (EU) as the final phase envisaged in the Ankara Agreement of Turkey's preparation for EU membership. It covers only industrial products and processed agricultural products. The positive effects of the $C U$ on trading volume are undeniable for both signatories, but there are several problems, especially for Turkey, that increasingly lessen the worth of CU. Since 1996, the context of the free trade agreements signed by the $E U$ with other countries has become more comprehensive than the CU between Turkey and the EU. On the other hand, the ongoing negotiations for a trade and investment deal with the US and EU seems to put the CU into a troublesome position. Because of the reasons above, this paper aims to examine the need for a modernized EU-Turkey Customs Union and possible revisions that can be made to refresh relations in light of the ECJ's decisions.

Keywords: Customs Union, Turkey, the EU, Free Trade Agreements, Decision No. 1/95 of the Association Council, Ankara Agreement, Additional Protocol.

\section{Introduction}

The only country that has been waiting at the entrance gate of the European Union (EU) since 1963 is Turkey. Even though the ultimate aim of the relations between the parties is the accession of Turkey to the EU, according to Article 28 of the Ankara Agreement (AA) (1963), the former is still a candidate country. This is due to several political reasons asserted by both parties. The roadmap for the full membership of Turkey has been prepared in Ankara Agreement consisting of three main steps named "preparatory", "transition" and "final". The Customs Union (CU), envisaged as the final phase before Turkey's full membership (Kabaalioğlu 1998), was established by the Decision No. 1/95 of the EC-Turkey Association Council (Decision No. 1/95 1995) and entered into force in 1996.

Since 1996, the Customs Union between Turkey and the EU covers only the areas in which the European Union is competitive, such as industrial and processed agricultural products. Although it had a limited concept and problems emerged from its implementation, the positive effects of the $\mathrm{CU}$ on trading volume were undeniable for both parties, at first. But today, the CU is becoming more advantageous, particularly for Turkey because of its absence in decision making processes of EU's common commercial policy, visa requirement, deflection of trade, etc. Not only the new generation of free trade agreements

*Assistant Professor, Faculty of Law, Department of International and EU Law, Cukurova University, Turkey. 
signed between the EU and outside countries, but also the ongoing negotiations for a Transatlantic Trade and Partnership Agreement (TTIP) between the US and the EU, put the CU into a troublesome and controversial position for Turkey.

This study aims to analyse if there is a need for fundamental reforms of the $\mathrm{CU}$ between Turkey and the EU. In this regard, while the defects of the mechanism are scrutinized, the essential amendments required for an effective CU will be examined.

\section{The Customs Union between Turkey and the EU}

Besides having a long-term relationship, Turkey has a different status because of the customs union with the EU. Actually, Turkey and Greece are the only countries that had or have a CU with the EU with an accession perspective. Greece became a member state in 1981, and the CU fulfilled its duty as the final step on the road to full membership for Greece. The CU between Turkey and the EU has been envisaged for the same purpose in accordance with Ankara Agreement Article 28. Therefore, the CU is seen as a step that should be taken before joining the internal market, which will be possible by accession to the EU.

The Customs Union Decision constitutes 66 articles and 10 annexes. Besides provisions regarding the functioning of the customs union, dispute settlement (Articles 61-62) and decision making procedures (Articles 54-60) are established by the Customs Union Decision. Article 3 of the Decision No. 1/95 implies that the Customs Union between Turkey and the EU covers free movement of goods produced in the EU or Turkey and ones coming from third countries in the free circulation in the EU or in Turkey. However, the goods that can be in free circulation are only industrial and processed agricultural products.

In addition to the abolishment of quantitative restrictions and measures having equivalent effects on import and export, which are laid down under Articles 5-6 of the Decision No. 1/95, the free movement of goods requires, in accordance with Article 4 of the Decision No. 1/95, the elimination of import or export customs duties and charges having equivalent effect to prevent unfair competition.

Other provisions set forth in the Decision No. 1/95 under Articles 13 and 16 are related to the adoption of Common Customs Tariffs and the harmonization of Turkey's trade policy with the EU's common commercial policy. In that respect, Turkey is under the responsibility not only to act in line with the EU decisions regarding Common Commercial Policy, but also to accord its legislation on customs with that of the EU.

Apart from the problems that occurred from the Customs Union, its positive contribution to Turkish trade was undeniable until recently. First of all, being in a customs union with the EU has obliged Turkey to improve its products vis-a-vis European rivals and increased its market share in the global economy by transforming the Turkish economy from an agrarian to an industrial one (Goral and Dartan 2016, Kirişçi and Bülbül 2017). The quantitative data also approves 
the rise of Turkey's export volume. Turkey's bilateral trade with the US has increased by 130 billion USD since the entry into force of the Decision No. 1/95 to 2014 (Goral and Dartan 2016). Moreover, Turkey has become the sixth-largest trading partner of the US (World Bank Report 2014), as well as the fourth largest importer from and the fifth largest exporter to the EU in 2016 (Kirişçi and Bülbül 2017). Besides its economic contribution to Turkey's economy, the Customs Union triggered positive developments towards democratization that enabled Turkey to fulfil the criteria set forth for candidate countries to the EU (Kirişçi and Bülbül 2017).

Nevertheless, there are several problems that stemmed from the CU and have been ignored since 1996 because of the belief that the accession process would not take too long for Turkey. However, unlike Greece, especially due to political reasons, Turkey has not become a full member yet, and it seems that there is no chance of becoming one in the near future. During the last 22 years since the entry into force of the Decision No. 1/95, not only the number of member states but also trade relations with non-EU countries and the opportunities for trade and investment with the rest of the world have increased for the EU. On the other hand, since the WTO Doha Round negotiations have deadlocked, bilateral agreements have begun to be preferred rather than multilateral trade agreements because of the difficulty to agree upon a common denominator (Akses 2014).

Thus, the EU has redirected its trade policy towards finding new markets and has tended to sign bilateral free trade agreements with developing countries (Cengiz and Kurtbağ 2015). A similar development has also occurred in Turkey's trade policy. Turkey has constituted trade relations with areas outside the EU. Therefore, the changing trade policies of the EU and Turkey have contradicted each other and lessened the worth of the Customs Union (Cengiz and Kurtbağ 2015). For instance, while the EU's share in Turkey's foreign trade was approximately 55\% at the beginning of the Customs Union, the ratio has decreased to $37.7 \%$ in 2012 (Cengiz and Kurtbağ 2015).

In addition to the problems above, EU-Turkey relations are occasionally in crisis since the accession of Cyprus to the EU in 2004. In the negotiations, 18 of 35 chapters have been suspended by the EU, France and Cyprus on the grounds that Turkey has failed to extend the Ankara Agreement to include Cyprus. Moreover, Turkey's problems with democracy, political pluralism and human rights, as well as the significant degree of political and economic divergence between Turkey and the EU, give rise to privilege partnership suggestions from several EU member states, such as France and Germany. A privilege partnership suggestion, which is declared unacceptable by Turkey, impedes Turkey's progress towards EU membership. Hence, Turkish public opinion has begun to lose its interest towards EU membership, and the government has begun to look for cooperation with eastern organizations, like the Shanghai Cooperation.

Today, the relations between Turkey and the EU are still controversial and needs to revive. Therefore, the modernisation of the CU could be a solution and a necessity not only for revival of the relations between Turkey and the 
EU, but also for the disadvantageous position of Turkey in trade relations stemmed from the status quo of the CU (Pierini and Ülgen 2014).

\section{The Problems of the Customs Union}

The EU Customs Union was built on four main principles, which include no customs duties at internal borders between the EU Member States, common customs duties on imports from outside the EU, common rules of origin for products from outside the EU, and a common definition of customs value (40 Years of Customs Union 2016). In accordance with the CU between Turkey and the EU, these principles are also valid for both parties. In other words, the CU requires a Common Customs Tariff to be implemented on imports from a third country either to Turkey or the EU; no customs duties at borders between Turkey and the EU; common rules of origin for products from third countries, and lastly a common definition of customs value.

There are several problems regarding the implementation of the CU since the Decision No.1/95 entered into force. No amendment has been made to the Decision No.1/95, while EU foundational treaties and policies have been amended many times. Under these circumstances, new problems have been added to the existing ones.

The problems of the CU can be listed under five headings, which are decision making procedure, trade deflection, road transport quotas, visa requirement and limited CU coverage (Goral and Dartan 2016).

\section{Decision-Making Procedure Regarding Customs Union}

The problems regarding the decision making procedure in Decision no.1/95 emerged because Turkey was not able to become a member state for over 20 years. The decision-making procedure envisaged under Articles 54-60 in Decision No. 1/95 gives Turkey only the right to consultation on taking decisions relevant to the implementation of the $\mathrm{CU}$, which does not function effectively and efficiently. On the other hand, Turkey is under the obligation to act in line with the EU's Common Trade Policy, even though it does not take place in the decision making process (Kabaalioğlu 2010). The Customs Union between Turkey and the EU requires Turkey to implement the same customs policy towards third countries and the harmonization of Turkey's customs legislation with that of the EU (Özsümer 2016).

In accordance with Article 50/1 of Decision no.1/95, a Customs Union Joint Committee has been established in order to discuss and exchange views regarding the proper functioning of the CU. In other words, the Joint Committee is envisaged to enable Turkey to be effective on Common Trade Policy issues related to the CU by putting forward pros and cons about them. However, it is difficult to say that the Joint Committee serves that purpose because of the inadequate meeting frequency. Even though the Committee shall meet as a general rule at least once a month, in practice it meets once or twice a year (Avrupa Birliği Bakanlığı 2017). Therefore, implementing EU decisions relevant to the 
Common Trade Policy, which are taken irrespective of Turkey's opinion because of the improper functioning of the Joint Committee, puts Turkey in a disadvantageous position not only in the negotiations on a Free Trade Agreement (FTA) between the EU and third countries but also when determining the rules valid for Common Trade Policy (Goral and Dartan 2016).

If Turkey could become a member state of the EU, the decision making procedure set forth in the Decision No. 1/95 would not be a problem anymore since Turkey's participation in the EU decision making process in common trade policy would be possible (Cengiz and Kurtbağ 2015).

\section{Trade Deflection}

Apart from the CU, the EU has continued to develop economic relations with outside countries based especially on the FTA. As one of the important economic markets in the world, it is easy for the EU to sign FTAs with third countries that are willing to establish economic bonds with the EU. Whenever a FTA is signed between the EU and a third country, it has the potential to cause deflection of trade against Turkey. This is because of the accession right into the Turkish market obtained via the FTA, unless the same third country signs a separate FTA with Turkey. Since there is no provision under Decision No.1/95 that obliges third countries to sign a separate FTA with Turkey, the third countries that obtained indirect entrance into the Turkish market without paying customs duties are reluctant to sign a separate FTA with Turkey (Akses 2014). In addition to the reluctance of third countries regarding a FTA with Turkey, Turkey has automatically the burden to convince the country with whom the EU has signed a FTA in order to avoid possible damage in Turkish economy.

However, in addition to the FDAs, the ongoing negotiations to establish a Transatlantic Trade and Investment Partnership (TTIP) between the EU and the US have significant potential to cause deflection of trade and thus affect Turkey's external trade negatively. The parties of TTIP constitute approximately half of the world's gross domestic product and $1 / 3$ of the world's trade, which means that they have the power to determine the rules and methods of world trade (Akman 2013, Kirişçi 2013). If the TTIP is signed, US products will have the chance to enter the Turkish market without being subjected to customs duties via the EU, but Turkish products will have to face customs duties in order to enter the US market (Akman 2013). This situation might cause serious losses in Turkey's gross domestic product (Kirişçi 2013, Kirişçi 2015).

Moreover, Turkey is supposed to sign FTAs with third countries that not only the EU, but also the US, has FTAs with. Otherwise, Turkey's external trade balance deficit might increase. Another probable negative effect can be on potential trade deficit between Turkey and the US, unless Turkey becomes a party of the TTIP or signs a separate FTA with the US. The potential trade deficit might increase due to the TTIP between US and the EU (Cengiz and Kurtbağ 2015). 


\section{Visa Requirements}

Visa-free travel is one of the basic and irrevocable foundations of the internal market based on free movement, including free movement of services. The proper functioning of the $\mathrm{CU}$ is indirectly related to the free movement of services, which embraces visa-free travel for businessmen who are supposed to work for the CU (Kabaalioğlu 2010). On the other hand, visa requirement is an unsolved problem in EU-Turkey relations still today. In that respect, both the AA and the Additional Protocol (AP) signed on 23 November 1970 have provisions regarding free movement of services. In accordance with Article 14 of the AA, the parties are obliged to abolish the restrictions on freedom to provide services between them with regard to the relevant precepts of the founding Treaties (Articles 4955 and 56-62 TFEU). The Additional Protocol includes a standstill clause under Article 41, paragraph 1, which serves to prevent the parties from adopting new stricter restrictions on freedom to provide services between them from the date of entry into force of the Additional Protocol (Rogers 2000, Weiss and Kaupa 2014). Not only Article 14 of the AA, but also the standstill clause enshrined under Article 41/1, have been interpreted by the CJEU in light of visa requirements (Abdulnasır Savaş Case 2000, Tüm and Darı Case 2007).

With the Soysal and Savatl (Soysal and Savatlı Case 2009) decision, the CJEU clarified its approach on the right of visa-free travel for Turkish citizens by declaring that visa requirements adopted after the entry into force of the AP are accepted as restrictions and are contrary to the standstill clause due to the stricter entry conditions for Turkish citizens who wish to provide services in a Member State (Soysal and Savatl Case 2009, paragraphs 57, 62). In accordance with the case law of the CJEU, three member states, Germany, Denmark and the Netherlands, in the Schengen area transformed their visa requirements, instead of abolished them, towards Turkish service providers due to the standstill clause via European Commission initiative to prepare a Practical Handbook for Border Guards (2006) (Erdenir 2013).

In a legal framework, Turkish businessmen should have a visa-free travel right to at least Germany, the Netherlands and Denmark. Yet in practice, not only the three of them, but also all the countries in the Schengen area, require visas from Turkish businessmen in breach of relevant Articles and the case-law of the CJEU.

Visa requirements put Turkish businessmen in a disadvantageous position vis-a-vis their European counterparts to the EU because of the paperwork and the waste of time and money (Yazic1 2012). While European businessmen travel without need of a visa, Turkish businessmen face impediments, such as not joining an international exhibition or missing the opportunity for a trade relation due to delay in visa. Therefore, visa requirements constitute obstacles for free movement and the indirect functioning of the $\mathrm{CU}$.

\section{Road Transport Quotas}

The CU includes the free movement of goods. Both import or export customs duties and charges having equivalent effect and quantitative restrictions or 
measures having equivalent effect on imports and exports are restricted under Articles 4-6 of Decision No. 1/95 in order to prevent barriers against the free movement of goods and unfair competition between Turkey and the EU. Despite the provisions above, Turkey is faced with a quota applied to goods that are transported via road transport (Goral and Dartan 2016).

While in accordance with the case-law of the CJEU (Dassonville Case 1974), "all trading rules enacted by Member States which are capable of hindering, directly or indirectly, actually or potentially, intra-Community trade are to be considered as measures having equivalent effect equivalent to quantitative restrictions", unless they are justified as mandatory requirements (Cassis de Dijon Case 1979). Several member states have taken transit fees on grounds of road transport quotas from Turkish transit companies, which create an obstacle to the free movement of goods and the functioning of the CU. It is also stated in World Bank report as follows:

Road quotas and notable transit permits, create obstacles to the free movement of goods and impede transit traffic thereby hindering the full operation of the CU. In total, Turkey has road transport agreements with 58 countries of which 25 have achieved various levels of liberalization. In the EU, bilateral road transport agreements including quota negotiation Turkish road transport operators remain a sovereign attribute of the individual EU member states. By limiting the number of Turkish-registered vehicles that can carry goods in their territory, EU member states set limits on Turkish goods that can be transported to the EU by Turkish road transport operators (World Bank Report 2014).

\section{Limited Scope of the $C U$}

The CU between Turkey and the EU covers only industrial and processed agricultural products, whereas the new generation of free trade agreements between third countries and the EU are more comprehensive (World Bank Report 2014). The increasing number of the new generation free trade agreements brings the potential to make Turkey's trade power weak compared to its counterparts by squeezing Turkish goods out of the market since better terms are envisaged in the new agreements (Kirişçi 2015). For instance, when the TTIP is taken into consideration, Turkey seems to lose its trading power in the US market, unless the country either signs a much deeper FTA with the US or modernizes the CU with the EU because of the areas that the TTIP includes. As is mentioned by the World Bank "...if successful, (TTIP) would create a comprehensive FTA comprising nearly half of global economic output and 30 percent of world trade...". Nevertheless the agreement is supposed to include all aspects of trade (both goods and services), tariff and non-tariff barriers (especially regulations) and FDI.

The negotiations will also include discussions on government procurement, trade facilitation, environmental and labor policies, competition policy, state 
owned enterprises and intellectual property rights which means that the asymmetry problem for Turkey could get worse (World Bank Report 2014).

\section{Suggestions for a Modernized Customs Union}

Since its entry into force there has been no amendment made on the Decision No.1/95. As such, it is obvious that the CU needs to be updated in order to accommodate the new conditions of world trade. Turkey and the World Bank have offered similar suggestions for what revisions are essential for removing the problems of the CU (Damlac1 2014).

\section{Participation in Decision Making Process}

First of all, the consultation process laid down in Articles 54-60 of Decision No. 1/95 needs to be transformed into an effective procedure where Turkey can be influential in the decision making processes relevant to the CU. Even if the accession of Turkey to the EU is the best way to solve this problem, Turkey's membership does not seem to be possible in the near future. Thus, as it is also suggested by the World Bank, the inclusion of Turkey to the Common Commercial Policy can improve information sharing mechanisms between Turkey and the EU. In other words, getting Turkey's opinion on issues relevant to the CU by enabling the proper functioning of the Customs Union Joint Committee might be a solution.

\section{Preventing Trade Deflection}

Trade deflection can be prevented either by maintaining parallel negotiations among the EU, Turkey and any third countries or by inclusion of a provision that obliges third countries to sign a FTA with Turkey into the FTA between the third country and the EU. On the other hand, as it is mentioned above, if Turkey becomes a part of the decision making process with the power to be influential on decisions taken for the Common Commercial Policy, trade deflection can be prevented in advance by hindering decision making that will adversely affect Turkish trade.

\section{Abolishing Road Transport Quotas}

It is clear from the earlier case-law of the CJEU that the road transport quotas are charges having equivalent effect to the customs union. Therefore, they create obstacles to the free movement of goods and are prohibited under EU-Turkey Association Law. Despite the prohibition, several member states continue to implement this measure to the Turkish transportation company. The only solution is to abolish the road transport quotas applied to Turkish firms in accordance with the Customs Union. 
Recently, the CJEU gave a decision regarding the road transport quotas directly. The dispute brought before the Court was about a motor vehicle tax taken from persons operating heavy goods vehicles registered in Turkey and in transit through Hungarian territory (İstanbul Lojistik Case 2017). The question referred to the Court was if the tax constitutes a charge having equivalent effect to a customs duty within the meaning of Article 4 of Decision No. 1/95 or a measure having equivalent effect to a quantitative restriction and, accordingly, a measure contrary to Article 5 of Decision No. 1/95 of the Association Council.

The Court discussed the questions within the scope of the Customs Union and interpreted them in accordance with the interpretation of the provisions of the Treaty on the Functioning of the European Union in respect of the free movement of goods within the European Union (İstanbul Lojistik Case 2017, paragraph 44).

Consequently, the CJEU declared that the motor vehicle tax constitutes a charge having equivalent effect to the customs duty, which is restricted under Article 4 of Decision No. 1/95, by stating as follows:

"Moreover, the Customs Union necessarily entails the free movement of goods between the Member States. That freedom could not itself be complete if it were possible for the Member States to impede or interfere in any way with the movement of goods in transit. It is thereof necessary, as a consequence of the Customs Union and in the mutual interest of the Member States, to acknowledge the existence of a general principle of freedom of transit of goods within the European Union (judgment of 21 June 2007, Commission v Italy, C-173/05, EU:C:2007:362, paragraph 31 and the caselaw cited). Indeed, the Member States would contravene that principle if they were to apply to goods in transit through their territory transit duties or other charges imposed in respect of transit (judgment of 16 March 1983, SIOT, 266/81, EU:C:1983:77, paragraph 19) ".

"In the light of the foregoing, the answer to the first question is that Article 4 of Decision No.1/95 of the Association Council must be interpreted as meaning that a tax on motor vehicles such as that at issue in the main proceedings, which must be paid by persons operating heavy goods vehicles registered in Turkey and in transit through Hungarian territory, constitutes a charge having equivalent effect to a customs duty within the meaning of that article".

\section{Entitling the Right of Visa-Free Travel and Visa Facilitation}

The visa issue has been a controversial problem between Turkey and the EU for a long time. In order to ensure the functioning of the Customs Union properly, all the obstacles should be abolished, including the visa requirement set forth against Turkish businessmen. Even though the Customs Union does not cover service sectors yet, the free movement of goods directly are related to the development of bilateral trade relations between Turkish and European 
businessmen. In this respect, the free movement of Turkish businessmen is essential for the Customs Union.

However, the CJEU has given several decisions on behalf of the right of visa-free travel of Turkish service providers, which includes Turkish businessmen. In accordance with the case-law, only the member states that brought stricter visa requirements to Turkish service providers after the entry into force of the Additional Protocol for them are under the responsibility to apply the prior conditions that were in force. Considering that the visa requirements have been implemented since 1980 to Turkish citizens, several member states are under the responsibility to abolish the visa requirements today due to the case-law. Apart from the case-law, at least the member states that do not fall within the case-law should apply visa facilitation to Turkish businessmen in order to establish a modernized customs union between Turkey and the EU.

\section{Extending the Scope of the Customs Union}

Besides the changing and developing trade policy of the enlarged EU, the increase in global trade has encouraged the EU to sign deeper and more comprehensive free trade agreements called "new generation" with third countries. While the number and the scope of free trade agreements are extending, the CU between Turkey and the EU is becoming out-dated. New generation free trade agreements involve not only industrial products, but also services, public procurement and agriculture sectors on the contrary of Customs Union between Turkey and the EU. Thus, Turkey has begun to lose its competitive capacity vis-a-vis advantageous new counterparts of the EU, such as Japan, Morocco, Georgia, Ukraine, Korea, Canada and Tunisia (Kirişçi and Bülbül 2017).

As it is also suggested by the World Bank and Kirişçi and Bülbül (2017), extending the scope of the customs union to include sectors that are set out under the new generation free trade agreements (services, public procurement and agriculture sectors) would enable Turkey to have the same advantages as the parties of the new generation FTAs (Kirişçi and Bülbül 2017, World Bank Report 2014). Moreover, upgrading the scope of the CU could be beneficial, not only for Turkey, but also for the EU. In accordance with the World Bank's report, if services trade is included in the Customs Union, it would be a positive contributor to Turkey's economy because of the possible increase in the value of exports. Moreover, it would pave the way to increasing bilateral trade relations with the EU (World Bank Report 2014, Akses 2014). Regarding the public procurement and agricultural goods, a similar result could be seen. As Kirişçi and Bülbül (2017) state "...upgrading the customs union to cover trade of non-agricultural goods, services and government procurement would increase Turkey's GDP by 2.5 percent, along with a 95 percent increase in agricultural exports to the EU and up to a 430 percent in the country's services exports". 


\section{Conclusion}

The modernisation of the Customs Union has been on the EU's agenda since 2015. The European Commission prepared a proposal to extend the bilateral trade relations to areas such as services and public procurement in 2016, and it is still being discussed in the Council (European Commission 2018).

From the beginning of the Customs Union, trade relations between Turkey and the EU have increased, and the positive impact of the EU on Turkey's trade is undeniable. In this respect, Turkey is an important trade and economic partner, as well as one of the leading allies of the EU. The Customs Union not only improves the competitiveness of Turkey's economy, but also enhances the quality of the Turkish products. While world trade is changing into extensive bilateral trade agreements rather than multilateral ones, the customs union, which has not been amended since it entered into force, needs to be modernized both in scope and function because of the new generation free trade agreements and the improper functioning of the CU.

The reason to establish a CU between countries is to gain some privileges in strategic economic sectors. This purpose applies to the EU-Turkey Customs Union. As an associated country of the EU, while Turkey should have more trade privileges and an advantageous position than the non-associated countries who signed new generation agreements with the EU, in practice the situation is opposite. The extended scope and trade advantages provided in the new generation free trade agreements put Turkey into a disadvantageous position vis-a-vis parties of the new generation agreements. This renders the CU between Turkey and the EU meaningless. In other words, what is the purpose of being associated with the EU if countries that are not associated gain more than Turkey?

In conclusion, the modernisation of the Customs Union is needed for two main reasons. First of all, a modernized Customs Union with the suggestions above would not only help Turkey to regain its former trade privileges, but also serve for equity purposes by putting Turkey, an associated country, into an advantageous position vis-a-vis non-associated ones. Secondly, it would also pave the way for reviving the membership negotiations between the EU and Turkey, which are currently in a state of deadlock.

\section{References}

Additional Protocol (1970). Retrieved from https://eur-lex.europa.eu/legal-content/ EN/TXT/HTML/?uri=CELEX:21970A1123(01)\&from=EN. [Accessed 19 March 2018].

Akman S (2013) AB-ABD Transatlantik Ticaret ve Yatırlm Ortaklığ ve Türkiye. [EUUS Transatlantic Trade and Investment Partnership and Turkey]. Tepav Raporu. Retrieved from: http://bit.ly/2HMiy1d. [Accessed 8 February 2018].

Akses S (2014) The Revision of Turkey-EU Customs Union: An Imperative Need. 23 İktisadi Kalkınma Vakfi Brief. Retrieved from http://bit.ly/2G9pOqN. [Accessed 7 February 2018]. 
Ankara Agreement (1963). Retrieved from https://www.ab.gov.tr/117_en.html. [Accessed 6 February 2018].

Avrupa Birliği Bakanlığı (2017) Customs Union Joint Committee. Available at: https:// www.ab.gov.tr/46237_en.html. [Accessed 12 March2018].

Case C-37/98, The Queen v. Secretary of State for the Home Department, ex parte Abdulnasir Savas ECLI:EU:C:2000:224.

Case C-16/05, Tum and Dari ECLI:EU:C:2007:530.

Case C-228/06, Mehmet Soysal and Ibrahim Savatlı v. Bundesrepublik ECLI:EU: C:2009:101.

Case 8/74, Procureur du Roi v Benoît and Gustave Dassonville ECLI:EU:C:1974:82.

Case 120/78, Rewe-Zentral AG v Bundesmonopolverwaltung fur Branntwein ECLI:EU: C:1979:42 (Cassis de Dijon).

Case C-65/16, Istanbul Lojistik Ltd v Nemzeti Adó- és Vámhivatal Fellebbviteli Igazgatóság, ECLI:EU:C:2017:770.

Cengiz C, Kurtbağ Ö (2015) Türkiye-AB gümrük birliğinde yaşanan güncel sorunlar ve bunlara olası çözüm önerileri. [The current problems of the EU-Turkey customs union and possible solution suggestions]. Akademik Yaklaşımlar Dergisi 6(2): 1-33.

Damlacı C (2014) Yeni Nesil Serbest Ticaret Anlaşmalarının Türkiye-AB Gümrük Birliği İlişkisine Etkisi. [The Effect of the New Generation Free Trade Agreements on EU-Turkey Customs Union]. In B Akçay (ed) Türkiye-AB ilişkileri: Yeni Gündem, 161-173. Ankara, Türkiye: Seçkin Yayınları.

Decision No. 1/95 of the EC-Turkey Association Council. Retrieved from: http://bit. ly/2pmAbxs. [Accessed 6 February 2018].

Erdenir B (2013) Vize. [Visa]. In B Akçay, S Açıkmeşe (eds) Yarım Asrın Ardından Türkiye-Avrupa Birliği İlişkileri, 471-492. Ankara, Türkiye: Turhan Kitabevi.

European Commission, EU and Turkey. Retrieved from: http://bit.ly/2HIUNXO. [Accessed 12 February 2018].

Goral E, Dartan M (2016) The Customs Union in the Context of EU-Turkey Relations: An Evolution of Current Debates. Marmara Avrupa Çalışmaları Dergisi 24(2): $1-31$.

Kabaalioğlu H (1998) The Customs Union: A Final Step Before Turkey’s Accession to the European Union. Marmara Avrupa Çalışmaları Dergisi 6(1): 113-140.

Kabaalioğlu H (2010) Turkey-EU Customs Union: problems and prospects. Dokuz Eylül Üniversitesi Sosyal Bilimler Dergisi 12(2): 47-57.

Kirişçi K, Bülbül O (2017) The EU and Turkey need each other. Could Upgrading the Customs Union be the Key?. Brookings Institution (2017). Retrieved from: https:// www.brookings.edu/blog/order-from-chaos/2017/08/29/the-eu-andturkey-need-eachother-could-upgrading-the-customs-union-be-the-key/. [Accessed 6 February 2018].

Kirişçi K (2013) Turkey and the Transatlantic Trade and Investment Partnership: Boosting the Model Partnership with the United States. The Brookings Institution, Turkey Project Policy Paper, No. 2 (2013). Retrieved from: http://brook.gs/2FK MPAK. [Accessed 8 February 2018].

Kirişçi K (2015) TTIP's Enlargement and the Case of Turkey. Turkey Papers. İstanbul Politikalar Merkezi and Wilson Center (2015). Retrieved from: http://bit.ly/2FM hBJF. [Accessed 8 February 2018].

Özsümer S (2016) Türkiye-Avrupa Birliği Gümrük Birliği Anlaşması ve Yeni Düzenlemeler [EU-Turkey Customs Union and New Arrangements] Izmir Ticaret Odasl, (2016). Retrieved from http://bit.ly/2uagG01. [Accessed 8 February 2018].

Pierini M, Ülgen S (2014) A Moment of Opportunity in the EU-Turkey Relations. Carnegie Europe, (2014). Available at http://ceip.org/1Df39SJ.

Practical Handbook for Border Guards (Schengen Handbook) [2006] OJ L 405. 
Rogers N (2000) A Practitioner's Guide to the EC-Turkey Association Agreement. Netherlands: Kluwer Law International.

Weiss F, Kaupa C (2014) European Union Internal Market Law. Cambridge, UK: Cambridge University Press.

World Bank Report No. 85830-TR (2014) Evaluation of the EU-Turkey Customs Union (2014).

Yazıc1 H (2012) Turkey-EU Relations and the Customs Union: expectations versus the reality. Turkish Policy Quarterly 11(1): 25-37.

40 Years of Customs Union (2016) European Commission. Retrieved from http://ec.eu ropa.eu/taxation_customs/40customs/customs_general_info/about/index_en.htm. [Accessed 7 February 2018]. 
